\title{
Urinal or conduit? Institutional information flow between the UK intelligence services and the news media.
}

Paul Lashmar, Brunel University

Abstract:

Since the 1990s, the Secret Intelligence Service (MI6) and the Security Service (MI5) have developed formal links with most major UK news organizations in an effort to improve the agencies' media presentation. This paper discusses the impact and inherent problems of these relationships, including whether the news media can have official, formal but nonattributable links with these agencies without compromising their role as the fourth estate.

Utilizing epistemologies for crime reporting and news sources, this paper proposes an initial framework to analyze these institutional relationships. It also takes as a case study the controversy over whether the MI5 deliberately played down their prior knowledge of 7/7 suicide bomber Mohammed Sidique Khan. The author was one of the journalists briefed by MI5 on Khan and has here take the Khan controversy as a case study to investigate the Security Services' information flow and whether the agency misled, and indeed intended to mislead, the media and the public.

Keywords:

MI5, MI6, Security Service, Secret Service, transparency, intelligence agencies, primary definers, news sources, accredited journalists

***

\section{Urinal or conduit? Institutional information flow between the UK intelligence services and news media.}

Introduction

The appropriate and effective function of the intelligence services is crucial for the maintenance of democracy. History teaches us that these agencies are prone to mission creep into the political realm and thus they need the independent scrutiny of the fourth estate. (Carlyle, 1841) The media also need information about the operational aspects of these agencies to fulfill their primary duty to their public of accurate and insightful reporting.

'Despite the prolific press coverage of the intelligence services since 9/11, the interaction of this secret realm of government with the media has received little sustained analysis,' Professor 
Richard Aldrich observed in Spinning Intelligence, the 2009 edited collection that went some way to correct this deficit.

The Security Service (MI5) and the Secret Intelligence Service (MI6) are key elements in the intelligence network that includes the eavesdropping agency GCHQ and also groupings such as the Joint Intelligence Committee which provide overall analysis and assessments. Neither MI5 nor MI6 have press offices. GCHQ does have a press office but it does not discuss intelligence matters only community and administrative issues. The author has been an investigative journalist in the UK national media for three decades with specialist knowledge of intelligence. While working for Independent Newspapers he dealt with intelligence agencies up to 2008, including the controversial 'Weapons of Mass Destruction", 7/7 and 'extraordinary rendition' briefings. This paper focusses on the institutional relationship between MI5 and MI6 and the major news media. It begins by providing a historical account of the institutional relations between UK intelligence agencies and the media. It then examines the formal if disguised relationships that have been developed since the 1990s by MI6 and MI5 with major news organisations in an effort to improve media relations. Using these formal but disguised links with the mainstream media the intelligence services incorrectly briefed there were WMD in Iraq as late as four weeks after the 2003 invasion. In terms of this paper two key questions arise from the WMD controversy:

Do these links serve the public interest?

Can there be trust between the intelligence services and the media?

Certainly the media failed in their fourth estate role to effectively interrogate the intelligence based assessments of Iraq's Weapons of Mass Destruction in both the UK and the US. It is now commonly accepted that the Western allies went to war in Iraq on a false premise as a result of the manipulation and exaggeration of intelligence data. MI6's role in the WMD controversy raised serious fourth estate issues. Unfortunately WMD is a difficult example to use as a case study for reasons outlined below. To examine these issues the author has chosen as a case study the controversy over whether the Security Service (MI5) deliberately played down their prior knowledge of 7/7 suicide bomber Mohammed Sidique Khan. This case study lends itself to audit.

Building a framework

The existence of formal links between intelligence organisations and the media places an imperative on finding a theoretical framework to analyse the consequences of these institutional relationships. In the absence of a suitable or comparable framework within intelligence epistemology this papers turns to media theory. The opaque nature of the intelligence services makes it difficult for the media to exercise an informed and coherent critique of the performance of the intelligence agencies. Christopher Andrew has pointed out: “The 'under-theorisation' of intelligence studies is not simply a problem for academic research. It also degrades much public 
discussion of the role of intelligence. Since September 11, 2001, the media and even some learned journals have been full of claims of 'intelligence failure'. But the majority of those who use the phrase seem to have no coherent idea of what it means. Clearly, a lack of a 100 per cent success rate does not constitute failure." (Andrew, 2004, 181) Andrew is right as most of the news media are stuck in a "success" or "failure" binary that does not serve their audience well.

Since the 1970s theorists have sought to build a framework for the discussion of news processes. A detailed critique of crime reporting has been central to this framework. It was also one of the first areas to consider the impact of news sources, focussing on the ability of the police to set the news agenda. This discourse can be seen as useful template to begin to discuss intelligence sources, not least as there are similarities between the police and intelligence agencies as institutions. In the 1970s social scientists from the 'Deviance' school formulated important theory on the nature of the news media. In their seminal study on the construction of the offence of 'mugging' in 1978 Stuart Hall et al expanded on what Becker (1972) had called the 'hierarchy of credibility' and suggest 'the likelihood that those in powerful or high status positions who offer opinions about controversial topic will have their definitions accepted, because such spokesmen are understood to have access to more accurate or specialised information on particular topics than the majority of the population. The result of this structured preference is that these spokesmen' become what we call primary definers of topics.' (Hall et al, 1978, 58) Hall et al argued that the media direct the debate by giving voice to the primary definers; who then set the limit for all subsequent discussions of the topic. 'This initial framework then provides criteria by which all subsequent contributions are labelled as "relevant" to the debate or "irrelevant" - beside the point. Contributions which stray from this framework are exposed to the charge that they are "not addressing the problem." (Hall et al, 1978, 59) The importance of this work was that Hall et al were able to show how the news agenda could be manipulated.

Other theorists complemented Hall et al's work, including Chibnall's work on crime reporting, contribution to the second edition of The Manufacture of News and in Law and Order News. This also suggested that the police could act as primary definers, setting the agenda for the way the crime was reported and thus perceived. Over the intervening years more subtle theory has evolved from this work critiquing the hegemonic aspect of Hall et al analysis. Schlesinger and Tumber gave a more nuanced take on primary definers. (Schlesinger and Tumber, 1994, 17-21). Simon Cottle was critical of shortcomings but observed Hall et al's early work had the advantage of "identifying the structural and institutional linkages between the mass media and other centres of power - linkages that can be examined and that promise to help explain the 'hierarchies of credibility' and the differential opportunities of media access granted by the mass media to contesting...voices and interests" (Cottle, 1998, 18)

The intelligence services are perhaps the most difficult institutions of state for the news media to exercise the role of the fourth estate by dint of those organizations' inherent penchant for 
secrecy. Unlike crime reporting, the information flow takes place almost entirely outside of the public sphere and is not attributed. The importance of the fourth estate task is reflected in that the intelligence services, Secret Intelligence Service (MI6) and the Security Service (MI5), have historically been proven to have directly and covertly intervened in the democratic process not only abroad but in the UK, sometimes at the behest of government and sometimes not. Prime Minister Harold Wilson was convinced that MI5 was undermining his Labour Government and was even concerned that senior intelligent officials were planning a right wing coup (Leigh, 1988) (Wright, 1987) (Cudlipp, 1976, 326) (Ramsay and Dorril, 1992). So how can journalists monitor the activities of intelligence agencies to ensure they act in the best interests of liberal democracy? There has to be some form of contact but not so that the media become mere mouthpieces for the intelligence services.

The history of intelligence agency links to the media

Prior to the 1990s in terms of their remits MI5 and MI6 should have had no official interest in entering the public sphere. However, while Britain's intelligence and security entities have been cloaked by secrecy and anonymity, they have a long history of 'under the table' informal links with journalists. These controversial links go back to the early days of the modern intelligence services. Many senior national media journalists, especially in the first half of the $20^{\text {th }}$ Century, had worked in intelligence at some point in their careers, often during wartime. Phillip Knightley noted "many journalists thought they could best help defeat Hitler by writing propaganda for one of the information offices or by serving in one of the secret services" (Knightley, 2006, 7) Access to inside information from within the intelligence services was and is a career enhancing facility for journalists. The covert flow of intelligence information to selected journalists reached its peak in the decades after the Second World War. As the diplomatic relationships between the West and the Communist bloc froze, the Foreign Office's Information Research Department (IRD) was launched under the Labour Government in 1948 and clandestinely financed from the Secret Intelligence Service budget. A large organisation with close links to MI6 (with whom it shared personnel), IRD waged a vigorous covert propaganda campaign against Communism for nearly thirty years supplying carefully selected journalists, politicians, academics and trade unionists with intelligence data. (Lashmar and Oliver, 1998, cover) IRD's work was officially sanctioned and a key part of its role was to create a cordon sanitaire so that government inspired information was placed in the public sphere but without attribution.

Urinal or conduit?

Having worked in defence during the Second World War, Chapman Pincher was the first journalist to cover the world of spying in depth, mostly for the Daily Express. Pincher's journalism has always been controversial. He was the target of historian E.P.Thompson's famous caustic observation that, Chapman was 'the urinal where Ministers and officials queued up to 
leak to'. It is a remark in which Pincher takes perverse pride. In 2009, he wrote: 'It is satisfying, at the age of 94 , to look back on a career in investigative reporting spanning more than sixty years - in various media - and to know that I would choose to repeat it in preference to any other profession.'(Dover and Goodman, 2009, 149). The urinal remark points to the problems facing of journalists of maintaining high quality sources while remaining independent.

Wherever British intelligence and security services have operated there are issues over selected leaking and disinformation. Northern Ireland was infamous as documented by Curtis (1984), Bloch and Fitzgerald (1979) and Miller (1994). We get occasion glimpses of deliberate intelligence leaks into the public sphere through trusted journalists. In the late 1990s The Sunday Telegraph alleged the son of the then Libyan Leader Colonel Gaddafi was involved in a criminal enterprise with Iranian officials that involved counterfeit notes and money laundering in Europe. This backfired as the Sunday Telegraph could not evidence the allegations and the resultant libel action ended up with the paper paying damages. The story was written by Con Coughlin, the paper's then chief foreign correspondent, and it was attributed to a 'British banking official'. It emerged in the trial that in fact, it had been given to him by MI6 officials. (Leigh, 2000). This appears to have been an officially sanctioned informal leak.

Investigative Journalism

Post-WW2, the national security consensus began to break down with the emergence of societal change, scepticism and a non-compliant breed of journalists. At that time, except for the chosen, the working journalist had no direct access to the agencies that were not officially acknowledged to exist by Government. Questions were directed to designated Home Office or Foreign Office press officers who usually were, I can vouch, at best, evasive. (The CIA and FBI have both had Public Affairs office for decades although this does not automatically improve relationship with the media.) A wave of media investigations into the CIA and other American agencies from the late 1960s revealed wholesale range of illegal, anti-democratic activity and paralyzing internal bickering was exposed. The same happened in the UK where extensive illegal and politically partisan action by the intelligence services was gradually revealed. British intelligence was revealed to have been involved in many coups from Iraq to Indonesia, often with unintended and unfortunate consequences. (Lashmar and Oliver, 1998, 1-10) It was the new breed of journalists who manifestly exercised the fourth estate role and the scrutiny was much needed. During the Cold War MI5 had applied questionable methods against those they perceived to be on the left and it had trouble distinguish the currents of the New Left from the pre-war old school sympathy for communism. MI5 systematically and secretly blacklisted many people applying for jobs in the BBC, sometimes on the basis of inaccurate information. A 'christmas tree' marker was placed on the files of such suspect applicants. (Leigh and Lashmar, 1985) Here we find MI5 covertly denying the rights of other to enter the public sphere. The publication of Spycatcher, by the former senior MI5 officer Peter Wright, despite British Government legal action, revealed 
MI5 to be a department riven by internal factions (Wright, 1987). The book was published in Australia to defeat a ban and lengthy legal action by the UK government.

Professor Richard Keeble examined a wide range of claims of inappropriate relationships between intelligence agencies and journalists. He concluded: 'Thus from this evidence alone it is clear there has been a long history of links between hacks and spooks. But as the secret state grows in power, through massive resourcing, through a whole raft of legislation - such as the Official Secrets Act, the anti-terrorism legislation, the Regulation of Investigatory Powers Act and so on - and as intelligence moves into the heart of ex-British leader Tony Blair and prime minister Gordon Brown's ruling clique so these links are even more significant.'(Keeble, 2008)

\section{Partial Glasnost}

Post-Cold War there was growing pressure for Freedom of Information, transparency and accountability in Whitehall. Sometime at the beginning of the 1990s, MI6, supported by the then Prime Minister John Major, decided the time had come for the agencies to develop more formal (if still anonymous and opaque) relationships with some major media organisations. The old wartime 'old boy's network' relationships had faded (though they had not totally disappeared) and were to be replaced with a modern make-over. (Whether this was a modernisation or a response to a reduced ability to access the public sphere to influence debate, or part of the effort to find a post-Cold War role is not yet clear.) As a trial, MI6 was prepared to talk to one link reporter in a small number of major UK media organisations. David Rose, then home affairs editor of The Observer has described the process. He was proposed as intermediary between the paper and MI6 by the then editor, Donald Trelford. In May 1992, over lunch his new MI6 contact (who he gives the pseudonym Tom Bourgeois) told Rose that MI6 'had always had a few, very limited contacts with journalists and editors, it now felt the need to put these arrangements on a broader and more formal basis.'(Rose, 2007).

Our conversations would not merely be off-the-record, and hence attributable in print to an unnamed MI6 official. In public I would have to pretend they had never happened, and if I wanted to quote or paraphrase anything Bourgeois said, I would have to use a circumlocution so vague as to make it impossible for any reader to realize that I had spoken to someone from the Office at all. Should I breach these conditions, Bourgeois made clear, I could expect instant outer darkness: the refusal of all future access.

What we see here is gear change in the institutional relationship, as it is official, acknowledged by both sides, but not attributable. David Rose says he had had stories leaked to him by MI6. So the intelligence services were keen to take the opportunity to be proactive primary definers in the public sphere and on occasion shape the news agenda. 
Accredited journalists

Over the 1990s, the experiment was deemed a success and extended to a wider range of news organisations. Expanding the franchise though, meant the 'rules of engagement' were to become tighter. Under the new arrangements the agencies were not to 'plant' stories, at least not to the new intake of accredited journalists. So in exchange for a wider set of institutional links the agencies were prepared to become passive primary definers responding to stories but able to retain some control over their shape. Later, the Intelligence Select Committee Report for 2004-5 described the arrangement publicly:

'Currently, a number of media outlets have a journalist 'accredited' to the Security Service and/or the SIS; these journalists are able to contact the Services for guidance. In turn, they are briefed by the Security Service or the SIS about matters relevant to the Services. The agreement between the Agencies and journalists is that all these contacts are off-the-record and must not be quoted directly..... Both the Security Service and the SIS told us that they deal only with journalists who have a reputation for discretion and professionalism.'

In addition the intelligence agencies instigated a policy whereby the heads of the agencies would speak publicly from time to time providing an overview of the work their agencies undertook and the level of threat. Through this we can see the intelligence agencies seeking to be primary definers and set parts of the debate. Public speaking by the heads of agencies is used sparingly usually at a major event or committee hearing but it falls entirely within Hall et al's concept of a primary definer.

My own experience as an accredited reporter with the intelligence services began, some years after David Rose, while working for Independent Newspapers. Intelligence and terrorism was part of my beat and the approach was direct. The first meeting with the MI5 link man was in a restaurant amusingly called 'KGB' in Central London. Further meetings occurred about every six months to a year. Meanwhile there were many phone calls, especially when terrorism was in the news. The terms were very similar to those spelt out to David Rose. There would be no direct quotes attributable to MI5 instead the sources would be much vaguer usually 'a Whitehall source'. MI5 were not keen on the phrase 'a security source'.

There are the ever present dangers in the relationship between journalists and their sources especially when sources want to protect their anonymity. (Franklin and Carlson, 2011) In 2002 Martin Bright, who was then Home Affairs Editor of The Observer and the link to MI5 wrote a critical article on the accredited journalist relationship. 'Most journalists agree that this is less compromising than the old system, but it is far from ideal,' he said.

'Most journalists feel that, on balance, it is better to report what the intelligence services are saying, but whenever the readers see the words "Whitehall sources" they should have no 
illusions about where the information comes from. In the period immediately following the events of September 11 and up to the new internment legislation, these journalistic briefings were used to prepare journalists for what was to come.' (Bright, 2002) It is worth quoting the Bright article at some length as it demonstrates the problems the anonymity brings:

... it is easy to spot where other such briefings have occurred, but I will give just one example. I have chosen it because of the impeccable reputation of the journalists concerned. It is from an article entitled 'MI5 searches for terror cells based in Britain' by Paul Lashmar and Chris Blackhurst in The Independent on 16 September 2001, less than a week after the attacks on the World Trade Centre and the Pentagon. Lashmar and Blackhurst are two of our most respected investigative journalists and were, at the time, in charge of investigations for The Independent.

The article shows that even journalists as experienced as they are were forced to fall back on intelligence sources when assessing the Islamist threat in Britain. They report that at least three terrorist cells linked to Bin Laden are at large in Britain and that the UK has been a major base for Bin Laden's operations. They add that there are believed to be dozens of terrorists in Britain associated with Bin Laden.

One 'intelligence source' is then quoted as saying 'There is no reason why what happened in America couldn't happen in Britain or any European country. The terrorists are in place, and there is very little to stop them.' A source, this time from 'Whitehall' adds: 'The problem is, these groups are amorphous and hard to identify until the they commit a terrorist act.' This is terrifying stuff and the two journalists concerned were right to report what was said to them - indeed, it is hard to imagine anything that was more in the public interest. But it seems a little disingenuous of the intelligence services to present this as independent evidence of the threat, when the journalists are simply reporting what they have been told. It is particularly difficult when it would appear that they contradict themselves when talking to other journalists.

Although it was not his intention, Bright reveals a problem caused by the agencies' attribution rules. The 'intelligence source' was not an official source and a personal contact that had previously provided me with material that was often critical of MI5 actions. (It was the same source that later warned me about the 'sexing up' of infamous Blair dossier see Whitaker et al, 2003) Bright is correct about the 'Whitehall source' being the MI5 official link. The vague attribution required by the accreditation agreement did create a lack of clarity and as we shall see the problems this created below is discussed in more detail below. These accredited intelligence contacts were to prove useful post 9/11 and they enhanced the Independent on Sunday's (I had changed newspapers by 9/11) coverage of the War on Terror. The Independent on Sunday team found that information from these contacts was measured and sensible. The MI5 liaison officials 
were scrupulous in maintaining the rules that had been first set out. At no time was a story offered by these sources.

\section{Weapons of Mass Destruction}

As the War on Terror progressed, serious questions arose about the veracity of intelligence based information released by government. Former senior intelligence official John Morrison has said that the Blair/Campbell school of media manipulation infected the agencies: "There was a culture news management which came in after 1997 which I had not seen before, and intelligence got swept up in that.' (Norton-Taylor and White, 2004) For the journalist access to high level sources is a great resource but it can be hard to resist the danger of 'going native'. Using the Hall et al model one can see that not only No10, MI6 and others sought to be the primary definers of the Iraq story and too often journalists obliged uncritically. One, David Rose, later wrote a mea culpa article for the News Statesman in 2007 admitting he had got too close to his intelligence contacts.

To my everlasting regret, I strongly supported the Iraq invasion, in person and in print. I had become a recipient of what we now know to have been sheer disinformation about Saddam Hussein's weapons of mass destruction and his purported "links" with al-Qaeda claims put out by Ahmad Chalabi and his Iraqi National Congress.

Rose added:

I remember one particular conversation I had with an official in the early summer of 2003, not long before Andrew Gilligan's BBC broadcast about the government having "sexed up" its dossier on Iraqi WMDs in September 2002. Already it was becoming apparent that the threat had probably been a chimera. "Don't worry," my source said soothingly. "We'll find them. We're certain they're there. It's just taking longer than we expected. Keep your nerve."

I too received these briefings and was consistently told with great certitude that there were WMD in Iraq. As late as four weeks after the invasion the press person for MI6 asserted confidently that they would find WMD. Unlike The Observer, the Independent on Sunday's collective position was of profound scepticism over WMD. Hall et al's words on primary definers are never more appropriate than with the intelligence services "such spokesmen are understood to have access to more accurate or specialized information on particular topics than the majority of the population." At the same time I was also dealing with non-official, long-standing contacts within the intelligence agencies. Talking to these unsanctioned contacts was difficult as the journalist must protect their sources and that's pretty tough when it comes to dealing with the spy world. It became very difficult around the time of the Kelly affair after the then Home Secretary John 
Reid lambasted unofficial sources as a 'rogue element' on the BBC's Today Programme specifically referring to my sources.

'......I said a rogue element because I thought there was one that was briefing Andrew Gilligan or indeed I said indeed elements because there may be the same source, there may be the same person, who is briefing the Independent on Sunday and various others, I don't know. But they are very much in the minority.'(Today, 2003)

The picture the insiders had given was different in key ways from the official line and helped produce much more nuanced journalism. As they were widely recognized as having entered the public sphere the intelligence agencies were now caught in the political crossfire. This raises the question is whether intelligence agencies can have formal links with the news media without risking the clandestine operating environment in which they need to protect national security? Two intelligence academics, Professor Anthony Glees and Dr Philip H. J. Davies argued in that the “....controversies over Iraq Intelligence are a direct result of John Major's Open Government Initiative - when the intelligence services are brought into the open they are inevitably politicised. They argued that the intelligence services should return to anonymity. (Glees and Davies, 2004)

A culture of selective leaking

An initial framework can be constructed to chart the institutional relationship can be structured in terms of the intelligence agencies entry into the public sphere and whether, when they seek to do so, it is on firstly, on an official or unofficial basis and secondly, whether it on an informal or formal basis. Information release into the public sphere by intelligence agencies seems to have several basic forms prior to the 1990s.

- Officially sanctioned but non-attributable information released to selected reporters from a major news organisation.

- Officially sanctioned exclusive leak to a selected reporter from a major news organisation.

- Information leaked by a senior official to a selected reporter from a major news organization without internal recrimination.

- Information leaked by an official to a selected reporter from a major news organization with possible internal recrimination. 
- Guidance on a specific story to a selected reporter from a major news organization informally by an official.

After 1990s we can add:

- Formal officially sanctioned but non attributable information released to all major news organisations.

- Formal guidance on a specific story to a selected reporter from a major news organization informally.

Outside the institutional information flow there have examples through the years from informal flow from, current or former, officials providing whistleblowing, dissident or alternative viewpoints. Peter Wright would be an example of a dissident former official entering the public sphere unsanctioned.

CASE STUDY: Mohamed Sidique Khan

Can the intelligence agencies be trusted to ever provide accurate information though the accredited journalism system? Surprisingly, this question has not been subject to any previous forensic analysis. Certainly the question is raised by the briefings on WMD but that controversy is not an ideal test case. The source of information in the build-up to the Iraq invasion tends to be so opaque and have such an international and broad political range of sources it is quite hard to tie down exactly what part MI6 played in supplying misinformation. It is hard to remove external political input from the equation. There are then several possible other case studies including the UK intelligence agencies knowledge and involvement in the United States' euphemistically named 'extraordinary rendition' operations. This paper examines the vexed issue of MI5's prior knowledge of 7/7 bomber Mohammad Sidique Khan to test the reliability of the intelligence services press briefings as it is possible to track key parts of the information flow. Input from politicians, MI6, or United States sources can be eliminated and so more readily can be seen as a litmus test of trust, at least with MI5.

Khan was the eldest of the four suicide bombers responsible for the 7 July 2005 London bombings, in which bombs were detonated on three London Underground trains and one bus in central London suicide attacks, killing 52 people excluding the attackers and injured over 700 people. It took the security services and police a few days to positively identify Khan and the other bombers. It was not until 12 July that they were certain it was Khan. The issue of trust revolves round whether Khan was previously known and identified by security forces and whether MI5 deliberately withheld and lied about that knowledge. As has been seen, David

$11 \mid \mathrm{P}$ a g e 
Rose's accuses MI5 of identifying the four bombers as 'clean skins' - unknown to the police. We, at the Independent on Sunday, became troubled by this issue as it became clear that MI5 had given us inaccurate information and that Khan had previously been under surveillance by the security forces. We had said that the bombers were unknown in the immediate aftermath and then reported as connections emerged. We were concerned that MI5 had deliberately misled us and this following research is partly motivated by the desire to resolve the issue. It certainly made us more wary of information passed through the accredited journalist system

David Rose's anger at being, what he believed were deliberate lies, is palpable in his mea culpa. After berating US sources for misleading journalists he moves on to the UK Security Service.

More recent media briefings seem equally questionable. After the 7 July 2005 London bombings, MI5 told its stable of reporters that the bombers had all been 'clean skins' who had been completely unknown to them; later they said there appeared to be 'no connection' between the $7 / 7$ cell and the failed 21/7 group who tried to repeat the atrocities a fortnight later. Only two years later, thanks to evidence given in criminal trials, did it become clear that both claims were false. In fact, the two leaders of the 7/7 gang, Mohammad Sidique Khan and Shazad Tanweer, had been observed by MI5 surveillance officers at least four times, and were known to be connected to another, now convicted, terrorist cell. But MI5 had decided to leave them alone while both men had apparently trained in Pakistan, at the same time as the 21/7 group. (Rose, 2007)

Within months of the suicide bombings there was a wide perception that MI5 had covered up its extensive prior knowledge of Khan to disguise the agency's incompetence, The Intelligence and Security Committee produced a report on in May 2006 into the 7/7 and 21/7 bomb plots. One of the Report's findings was that MI5 had come across two of the 7/7 bombers on the edge of other investigations. It said: 'A review of related surveillance data showed that Siddeque KHAN and Shazad TANWEER had been among a group of men who had held meetings with others under Security Service investigation in 2004.' These 'others' were the Operation Crevice group, a different bomb plot in which a number of people were arrested and later tried.(ISC, 2005) Since May 2006 more and more links emerged public demands for inquiry grew. Khan had been spotted by security forces with those later arrested for Crevice. Such was the public outcry that the Intelligence and Security Committee reinvestigated the issue and published a new detailed report in May 2009 (ISC, 2009). It is now certain UK security services had many more leads on Khan than they admitted non-attributably in 2005. The report revealed that Khan was under covert surveillance by the security services ten times before the launch of the attacks. (ISC, 2009). As late as May 2010 it emerged that fingerprints of Khan could have been on police records 19 years before the attacks 
The crux of the allegations we are concerned with here is that, in the immediate aftermath of the bombings, MI5 claimed the bombers were 'clean skins', i.e. not previously known to the Security Services. The Nexis electronic newspaper archive suggests the first published reference to 'clean skins' in this context come on $13^{\text {th }}$ July. The Birmingham Post reported: 'The security services were last night coming to terms with the nightmare scenario that the London bombers were ordinary citizens who had never come to the attention of the authorities. A senior security source said the existence of so-called 'clean skins' made the job of preventing further attacks even more difficult.

"How many clean skins have we got waiting in the wings?" he asked.'

The Belfast Telegraph ran an almost identically worded story. The repetition of the exact phrase suggests both papers used a Press Association (PA) News Agency report and sure enough there is a PA report on 12th July by Nick Allen and Neville Dean: 'Detectives and the security services fear there could still be a second suicide bomb team waiting to strike and that an al Qaida mastermind could have orchestrated the attacks before fleeing the UK.

The bombers appear to be the security services' worst nightmare, so-called 'clean skins', apparently ordinary young men who had not previously come to the attention of the authorities. 'How many clean skins have we got waiting in the wings?' a senior security source said. 'What we don't know is whether someone came in under the al Qaida methodology, whether they came in, did the preparation and left the country the day before the attacks.'

This report has been at the centre of allegations that MI5 misled the media and the public. One of the bylined reporters, Nick Allen, says of the quote from a 'security source': 'I'm afraid that definitely didn't come from the MI5 spokesman as I wasn't the accredited PA person and have never spoken to them. We would have picked it up from briefings at Scotland Yard. Confusingly, the anti-terrorist police often got referred to as 'security sources' at the time. From memory I think the phrase 'clean skins' was already in use in the US media and was being bandied around by journalists and police officers here.' (Nick Allen was at the time of writing The Daily Telegraph's U.S. Entertainment Correspondent based in Los Angeles) (Email correspondence with author 7 Oct 2010.)

The ISC report says; 'MI5 did not call the bombers 'clean skins'. This phrase is not one that MI5 use and they did not use it in relation to the bombers. MI5 have told the Committee that the phrase they used with the media was 'not on our radar', which was an accurate reflection of what they knew in the days immediately following the attacks. The Committee has also reviewed the Metropolitan Police Service's press releases, statements and question and answer material from 7 July to 10 July 2005 and can find no mention of the phrase 'clean skins'.

As the ISC says, the key question being asked was: 'If MI5 had come across Mohammed Sidique KHAN and Shazad TANWEER before, why didn't they prevent this outrage?' The ISC deal

$13 \mid \mathrm{P}$ a g e 
with this issue head on. 'Even though Sidique/Sidique/Sadique KHAN was not assessed to be significant, it is nevertheless surprising, given the amount of information MI5 and the police had on him, that they said they had not identified Mohammed Sidique KHAN prior to 7/7. We questioned MI5 in detail on this point.'

My notes for a telephone conversation with the MI5 link man on the $14^{\text {th }}$ July show I asked him about the 'clean skins' question. He did not say they were 'clean skins' but said that 'they were not on our radar' and one of the bombers was indirectly linked to Operation Crevice. This supports the ISC investigation statement. (In later conversations with the MI5 link man they start to amend their position saying that more evidence of prior knowledge had come to light.) The impression was of a fast moving and slightly chaotic situation. Later they were clearly embarrassed. It is likely the 'clean skins' quoted came from a senior police officer from the anti terrorist branch acting outside the police press office rubric, a not uncommon occurrence at the time. What we can see here are the perils for the intelligence agencies of being an official, formal, but non-attributable. The requirement on the media not to use precise attribution caused confusion for all involved and problems for MI5 that needed to be resolved by an inquiry. This could have been resolved by a more open system of attribution. It is hard for the reader to know what 'security sources' or 'Whitehall sources' actually are and this can be confused with other agencies including the police in their anti-terrorism role.

\section{A continuing relationship}

MI5 have sought to retain a good relationship with the media. This paper has discussed the functioning of the accredited reporter system but from the media's perspective. It is not easy to know what MI5 have made of it. MI5 press officers have occasionally fumed at what they perceived as inaccurate reporter or unjustified criticism. The only formal comment has come from The Director General of MI5, Jonathan Evans said, in an address to the media in 2007 said: 'I am, on the whole, impressed with the media's sense of responsibility and its understanding of our concerns. And as the demand for news increases, we cannot afford to let this understanding fall away, because there is no contract between the security and intelligence agencies and the media. There is no memorandum of understanding between us. It is a matter of trust.' (Evans, 2007) In 2004 Parliament's Intelligence and Security Committee briefly examined the relationships between the agencies and press. It took evidence and concluded: (ISC, 2004-5. pp 31-32)

Most of the witnesses from the media were content with the current mechanisms for contacting the Agencies. They commented that the Security Service was perhaps the easiest Agency to deal with, which they attributed to the Service's public protection role and need to communicate with the public at large, and that the SIS was the most difficult.

...... A further complication is that the public now questions the Agencies' ability to 
produce accurate intelligence, which puts pressure on the Agencies to show how and when their intelligence was accurate and useful.

The Government is trying to balance the need to inform people about issues that affect them, such as the terrorist threat to the UK, whilst still protecting the Agencies' work. This is a difficult balance, which requires further thought.

At the time of writing the system is still in place as described. I spoke to several reporters who are accredited. MI6 have moved from using a senior officer to recruiting a professional government information officer with previous experience in the Cabinet Office and Police. The heads of MI6 and MI5 lunch with editors and accredited journalists from major news organisations. One participant in these lunches observed that the information flow from the agencies tends to be more interesting and candid the higher the source is placed within the agency. The non-attribution rules still apply. Unusually, possibly unprecedented, MI6 was so heavily criticized, not least from the coroner, over the death of one of its officers, Gareth Williams, that stung into giving a statement to the Press Association defending its position and attributed to an 'SIS spokesman'. Examining academic analysis of crime reporting one is struck by other similarities. The intelligence agencies seem to be hesitantly following the police path of professionalization of media contacts and moving away from press contacts chosen from serving officers. As Schlesinger and Tumber have shown media contact can evolve moves from 'defensive and secretive' answering reporter's questions to managing information flow and image reconstruction (1994, 107-111)

\section{Conclusion}

As revealed in the examples above some journalists have rushed to judgment either prematurely, on the basis of personal embarrassment and with inaccurate information. Over my career I had been highly critical of the intelligence services over specific issues and the broader lack of accountability. It would be very easy to accuse them of seeking to use the institutional links with the news media to sow unattributed disinformation but the situation is more nuanced. There is compelling evidence MI6 was politicized at a senior level in after 9/11 and did proffer information as credible that in fact was poorly evidenced. The whole issue over the source known as Curveball was a nadir for the western intelligence community (Drogin 2007). Even the sceptic could be swayed by the certainty that emanated from MI6 about the existence of WMD and of Saddam Hussein's imminent aggression. If the UK media were too willing to publish the government's claims of WMD, eventually the media returned to their fourth estate role.

The evidence detailed above suggests MI5's record is better and the Security Service briefers did not deliberately lie over Khan. Early briefings did not accurately portray how frequently leader of the 7/7 bombers had come up on MI5's 'radar'. Perhaps they were suffering from the 'fog of war'; working on the best information available, while still analyzing and collating evidence. 
There is no evidence MI5 was politicised. My own non-official and proven inside sources of the time deny that MI5 became captive, like MI6, to the Downing Street's political agendas. The formal relationship between intelligence and news media remains difficult. In a couple of decades we have moved from a situation where the intelligence services used to say nothing or would only leak to their advantage, to a situation where they tried to respond to journalists in a fast changing situations. It is a very different problem. If the news media want fast moving operational information that later is proved not to be accurate journalist need to think carefully before accusing agencies of lying. David Leigh, investigations editor of The Guardian, has commented on the fraught relationship between agencies and journalists. As journalists, he says, "Our first task as practitioners is to document what goes on in this very furtive field. Our second task ought to be to hold an open debate on what the proper relations between the intelligence agencies and the media ought to be. And our final task must then be to find ways of actually behaving more sensibly. (Leigh, 2000)

This paper attempts to begin a framework for analyzing the institutional links between intelligence and the news media building on Hall et al work. We can see useful parameters in the unofficial/official axis and also the consequences of non-attribution.

As for the question: Does this system act in the public interest? The current system has eliminated much of the nonsense attributed to the intelligence services in the past. Generally, but not always, it seems to put accurate information into the public domain. The following points emerge:

- The jury is still out on whether the news media can trust the intelligence service briefings as problems have emerged in times of maximum stress.

- Overall the links have improved the accuracy of intelligence related information into the public domain.

- In the time of 24/7 rolling news it has a new set of problems that are hard to resolve professionally. Can journalists really have it both ways with an immediate response to any crisis and a guarantee that response has copper bottomed accuracy? The media cannot always do that, why should the intelligence agencies?

- The non-attributable sourcing is confusing and needs to be changed to direct attribution to the source.

- It may now be time for the agencies to have proper press offices so that they can be seen to be transparent and participants in $21^{\text {st }}$ century democracy.

- It is now harder to develop informal, independent voices from within the intelligence agencies. In the past these voices have acted as important sources top rectify lack of transparency and accountability.

- It is possible for the news media to maintain its fourth estate role while maintaining links to the intelligence agencies but great care has to be taken to retain journalistic credibility in this unique relationship.

$\mathbf{1 6} \mid \mathrm{P}$ a g e 
References

Aldrich, R. (2001) The Hidden Hand: Britain, America and Cold War Secret Intelligence, John Murray, London. pp. 132-4

Andrew, C. (2004): Intelligence, International Relations and 'Under-theorisation', Intelligence and National Security, 19:2, 170-184

Becker, H. (1972) "Whose side are we on?” in The Relevance of Sociology, ed. J.D.Douglas. New York: Appleton-Century-Crofts

Bloch, J. and Fitzgerald, P. (1984) British Intelligence and Covert Action: Africa, Middle East and Europe Since 1945, London: Brandon Press

Bright, M, (2002) 'Terror, security and the media,' The Observer, 21 July 2002

Dover, R. and Goodman, M.S. (Eds). (2009) Spinning intelligence: Why Intelligence needs the media, Why the media needs intelligence, London: Hurst \& Co

Carlyle, T. (1841) On Heroes and Hero Worship. London privately published

Chibnall, S. (1982) “The Crime Reporter" in Stan Cohen and Jock Young, (Eds) The

Manufacture of News, 2nd ed. London: Sage

Chibnall, S. (1977) Law and Order News, London: Tavistock

Cottle, S. (1998) “Ulrich Beck, 'Risk Society' and the media, a catastrophic view?" in European Journal of Communication, 13(1):pp. 5-32

Cudlipp, H. (1976) Walking on Water. London: The Bodley Head

Curtis, L. (1984) Ireland: The Propaganda War, London: Pluto Press

Dorril, S. and Ramsay, R. (1992) Smear! Wilson and the Secret State. London HarperCollins; New Ed

Drogin, B. (2007). Curveball: Spies, Lies, and the Con Man Who Caused a War. New York: Random House

Evans, J. (2007),'Intelligence, counter-terrorism and trust', Address to the Society of Editors, Manchester 
Franklin, B. and Carlson, M. (2011) Journalists, Sources and Credibility: New Perspectives, London, Routledge

Glees, A. and Davies, P. (2004) Spinning the Spies: Intelligence, Open Government and the Hutton Inquiry, London: Social Affairs Unit

Hall, S. Critcher, C. Jefferson, T. Robert, B. and Clarke, J. (1978) Policing the Crisis, Mugging, the State and Law and Order, London: Palgrave Macmillan.

Intelligence and Security Committee Annual Report 2004-5. pp 31-32

Intelligence and Security Committee Report into the London Terrorist Attacks on 7 July 2005 (52 pages)

Intelligence and Security Committee Report: "Could 7/7 Have Been Prevented? Review of the Intelligence on the London Terrorist Attacks on 7 July 2005”, HMSO. May 2009

Keeble, R.L. (2008) Uncovered: British reporters who are spooks. The-Latest.com. 2 July 2008

Knightley, P, (2006) "First Casualty: The War Correspondent as Hero and Myth-Maker from the Crimea to Kosovo", John Hopkins University Press

Lashmar, P, and Oliver, J. (1998) Britain's Secret Propaganda War: A History of the Foreign Office's Information Research Dept 1948-77) Stroud: Sutton

Leigh, D, and Lashmar, P. (1985) 'Revealed: How MI5 vets BBC staff', The Observer, 18 August 1985, pg 1.

Leigh, D. (1988) The Wilson Plot: How the Spycatchers and Their American Allies Tried to Overthrow the British Government. Pantheon Books

Leigh, D. (2000) 'Britain's security services and journalists: the secret story' British Journalism Review, 11/2, pp. 21-26

Miller, D. (1994) “Don’t Mention the War”. London: Pluto Press

Schlesinger, P. and Tumber, H. (1994) Reporting Crime, Oxford: Clarendon

Norton-Taylor, R. and White, M. (2004), 'Blair Misused Intelligence, Says Ex-Spy Officer,' The Guardian, 29 October 2004.

18 | P a g e 
Rose, D. (2007) “Spies and their Lies", News Statesman, 27 September 2007. Can be seen at: http://www.newstatesman.com/politics/2007/09/mi6-mi5-intelligence-briefings.

Today Programme, 4 June 2003 transcript to be found:

http://www.guardian.co.uk/politics/2003/jun/04/iraq.iraq

Whitaker, R. Lashmar, P. and McSmith, A. (2003), 'Revealed: How Blair used discredited WMD 'evidence: UK intelligence chiefs warned claim that Iraq could activate banned weapons in 45 minutes came from unreliable defector' Independent on Sunday. 1 June 2003

Wright, P. (1987) Spycatcher London: William Heinneman 